\title{
Interaction between Dalbergia sissoo Roxb. and Pseudomonas koreensis AS15 Strain is Cultivar Specific
}

\author{
Hemant Dasila ${ }^{1 *}$, Anjul Rana ${ }^{1}$, Damini Maithani ${ }^{1}$, Anamika Rana ${ }^{1}$, \\ Manvika Sahgal ${ }^{1}$ and Salil Tewari ${ }^{2}$ \\ ${ }^{I}$ Department of Microbiology, ${ }^{2}$ Department of Genetics and Plant Breeding, G.B. Pant \\ University of Agriculture \& Technology, Pantnagar, Uttarakhand, India \\ *Corresponding author
}

\begin{tabular}{|c|}
\hline Keywords \\
\hline $\begin{array}{l}\text { Dalbergia sissoo } \\
\text { seedling, Bioinoculant, } \\
\text { Pseudomonas koreensis, } \\
\text { Microbial enzyme } \\
\text { alkaline phosphatase, } \\
\text { Fluorescein di acetate } \\
\text { hydrolysis }\end{array}$ \\
\hline Article Info \\
\hline $\begin{array}{l}\text { Accepted: } \\
04 \text { September } 2018 \\
\text { Available Online: } \\
10 \text { October } 2018\end{array}$ \\
\hline
\end{tabular}

The genus Dalbergia comprises 300 species, of which nearly 25 species occur in India. One of the species Dalbergia sissoo Roxb vern.

\section{Introduction}

Shisham plantations and natural forests throughout sub Himalayas region, Indogangetic plains and Indian plateau region are facing large scale mortality. Seedling health is key to success of any tree plantation programme. Plant growth promoting rhizobacteria intimately interact with the plant roots and consequently influence soil microbial activity and seedling vigor. In present study, pot culture experiment was carried out under glass house conditions with two Dalbergia sissoo cultivars PS90 and PS52. The experiment was set in a completely randomized block design (CRD) and consisted of six treatments including controls with three replications in each treatment. During experiment seven day old seedlings of $D$. sissoo cultivars germinated from freshly collected seeds and subsequently treated with Pseudomonas koreensis AS15 strain by root dip method were planted in $1 \mathrm{~kg}$ capacity plastic pots. Artificial inoculation of $P$. koreensis AS15 enhanced the plant vigour parameters in both D. sissoo cultivars PS90 and PS52; PS 90 cultivar exhibiting higher shoot fresh weight $(5.8 \mathrm{gm}$ at $60 \mathrm{DAP})$ and shoot length $(45.6 \mathrm{~cm}$ at $60 \mathrm{DAP})$ than PS 52 , shoot fresh weight $(2.5 \mathrm{gm}$ at $60 \mathrm{DAP})$, and shoot length $(40 \mathrm{~cm}$ at $60 \mathrm{DAP})$ in two factor analysis of variance. There was variation in soil enzyme activities with respect to cultivars. The soil planted with PS90 cultivar exhibited higher alkaline phosphatase (AP) and fluorescein di acetate hydrolysis (FDA) activities as compared to those with PS52 cultivar seedlings. The enhanced plant vigor parameters and soil enzyme activities indicated that interaction of PS90 cultivar with inoculant strain was robust. The results indicated that response of $P$. koreensis AS15 inoculation is cultivar specific and can be used to raise disease resistant $D$. sissoo seedling that also sustain transplantation shock.
Shisham grows naturally in India and neighbouring countries Afghanistan, Pakistan, Nepal, Myanmar, Bangladesh, Malaysia and Sri lanka. In India it grows in foot hills of Himalayas upto $1000 \mathrm{~m}$ above sea level, 
Indogangetic plains central and peninsular region. It is internationally known for its priced timber and plays important role for country's economy. Additionally it is a pioneer tree species used for afforestation programmes, road side plantations, preparation of agricultural implements, its leaves are used as fodder and twigs as fuel wood. It is also used in folk medicines as remedy for gonorrhea and skin ailment. Being nitrogen fixing, Dalbergia sissoo adds biologically fixed nitrogen into the soil. It is well known that biological nitrogen fixation (BNF) brings more nitrogen in terrestrial ecosystem than any other natural input (Vitouset et al., 2013). Nitrogen fixing trees add more than $100 \mathrm{~kg} \mathrm{~N} \mathrm{ha}^{-1} \mathrm{y}^{-1}$ in tropical (Binkley and Giardina., 1997), temperate (Binklay et al., 1994) and boreal forests (Ruess et al., 2009). For these reason it is preferred for afforestation programmes. Shisham is grown both as monoculture or mixed crop (Bisht et al., 2009). Shisham is facing large scale mortality in both natural forests and plantations.

Both biotic and abiotic factors are known to be associated with shisham mortality which results in shisham decline. Soil factors are primary abiotic factors as main reason behind disease in sissoo plantation (Sah et al., 1999). According to Afzal et al., (2006) global warming and erratic rainfall could be one of the reasons for shisham decline. Water logged condition for a considerable period of time cause asphyxiation of the roots (Dayaram et al., 2003) and hence mortality. The abiotic factors can promote the growth of pathogenic microorganism in soil and rhizosphere. These pathogenic microorganisms ultimately infect shisham trees. Almost $70 \%$ of the shisham mortality is due to soil borne pathogens. The pests and nematodes are secondary factors. Both fungi and bacteria have been isolated from diseased shisham trees. Soil borne fungal pathogen like Fusarium solani (Sah et al.,
2003), Ganoderma lucidum (Ahmad et al., 2013) and Phytophthora cinnamoni (Gill et al., 2001) have been isolated from diseased shisham trees. Bacteria of genera Pseudomonas and Bacillus have been reported from diseased shisham trees in Bangladesh (Valdez et al., 2013).

Under this context it is of utmost importance to raise the seedlings that can withstand abiotic and biotic stresses by exploring the interaction of D.sissoo with beneficial microorganisms. Bacteria are ubiquitous to water, soil and plants. Of these rhizobacteria are known to be beneficial to plants through direct mechanism such as production of hormones, enzymes and metabolites (Ahemad and Khan 2012) for example indole acetic acid (IAA), ACC (1-minocyclo propane-1carbooxylate) deaminase, hydrogen cyanide $(\mathrm{HCN}), \quad$ ammonia production and dinitrogenase activity (Glick., 2012; Khan., 2005) facilitating plant uptake of macro and micronutrients from soil i.e chelation of iron through siderophore, providing plant available phosphorous through solubilization and minerlization, and indirect mechanisms such as biocontrol agents which either inhibit growth of phytopathogen or induce resistance in plants against pathogen attack. It is reported that inoculation of plant beneficial bacteria in soil or seed enhance the growth and yield in crops (Gholami et al., 2009) and trees (Saheen et al., 2014). There are reports that use bioinoculants during nursery establishment leads to healthy seedlings that can withstand both biotic and abiotic stress (Rincon et al., 2008). Padder and co-workers (2017) reported that biomass of D.sissoo seedlings was enhanced upon inoculation of rhizobacteria. Rhizobacteria belonging to genera Azotobacter, Arthrobacter, Azospirillum, Alcaligenes, Bacillus, Burkholderia, Enterobacter, Pseudomonas and Serratia are commonly used bioinoculants (Ahmed and Kibret, 2014). Amongst these, Pseudomonas 
has been identified as one of the largest and most promising potential group of PGPR due to their simple nutritional requirement, robust colonization ability and substrate versatility. Pseudomonas inoculants significantly increased root dry weight in spring wheat (Walley and Germida, 1997) and yield in sugar beet (Cakmakc, et al., 2001). Moreover Rahmoune et al., (2017) also reported the positive impact of inoculation of Pseudomonas genera on Arabidopsis and Datura plants. In this study P. koreensis was inoculated on D. sissoo seedlings and its response on seedling health and soil equality was assessed. The soil enzyme activities have been suggested as a suitable indicator of soil quality. They are a measure of the soil microbial activity and therefore are strictly related to the nutrient cycles and transformation. They respond rapidly to the changes caused by both natural and anthropogenic factors (Frac, and JezierskaTys, 2011). Therefore in this study we evaluated how inoculation of $P$. koreensis affects soil enzymatic activities as well as overall growth of $D$ sissoo seedlings.

\section{Materials and Methods}

\section{Glass house pot trial}

The pot trial was performed in three replication of each treatment. The pots were arranged in completely randomized block (CRD) design under glass house condition at AFRC (Agroforestry Research Center, G.B.Pant University of Agriculture and Technology, $28^{\circ} 58^{\prime} \mathrm{N} \quad 79^{\circ} 25^{\prime} \mathrm{E} / 28.97^{\circ} \mathrm{N}$ $79.41^{\circ} \mathrm{E}$ ) Pantnagar. The nursery trial with seven days old seedling of two disease susceptible D.sissoo cultivars PS90 and PS52 was carried out in $1 \mathrm{Kg}$ capacity polythene bags filled with sterile autoclaved soil and vermiculite in a 2:1 ratio (w/w). Shisham seedlings were bacterized by the root dip method (Shukla, 2008). The log phase broth culture corresponding to a population of $10^{8}$ CFU $\mathrm{ml}^{-1}$ of Pseudomonas koreensis were mixed with 1\% Carboxy Methyl Cellulose (CMC) and Gum Acacia (GA) in separate flasks. Both CMC and GA were used as adhering agents. Uninoculated seedlings were kept as control. Roots of shisham seedlings at 3-5 leaf stage of seven days plants were dipped in bacterial suspension for 30 minute. Bacterized seedlings of PS 90 and PS52 were transplanted one per each pot. Plants were watered regularly through splinker system in glass house. In all, there were six treatments; T1 (PS 90 Control), T2 (CMC + Pseudomonas koreensis), T3 (GA + Pseudomonas koreensis) T4 (PS52 Control) T5 (CMC+ Pseudomonas koreensis) and T6 (GA + Pseudomonas koreensis). Plants were uprooted carefully at 30, 45 and 60 days after planting (DAP) and analyzed for plant agronomical parameters (root fresh weight, shoot fresh weight, root length, shoot length and nodule number) and soil microbiological enzyme activities.

\section{Soil microbial enzyme activities}

The soil health was monitored by estimating activities of two soil enzymes fluorescein diacetate and alkaline phosphatase in soil from all six treatments during glasshouse trial. Fluorescein di-acetate (FDA) hydrolysis activity was evaluated according to method of Inbar et al., 1991. $1 \mathrm{gm}$ of fixed moist soil taken in Erlenmeyer flask was drenched with $1 \mathrm{ml}$ of FDA solution and $15 \mathrm{ml}$ of phosphate buffer. The flasks were shaken for $20 \mathrm{~min}$ on rotary shaker at $25^{\circ} \mathrm{C}$ after which $10 \mathrm{ml}$ of acetone was added for extraction. The absorbance of filtered samples was measured at $490 \mathrm{~nm}$.

Alkaline phosphatase activity was assayed according to method of Tabatabai and Bremner (1969). One gram of moist soil was placed in a $50 \mathrm{ml}$ Erlenmeyer flask, to which 4 $\mathrm{ml}$ of Modified Universal Buffer (MUB), 0.25 
$\mathrm{ml}$ of toluene; $1 \mathrm{ml}$ of $\mathrm{p}$ - nitrophenyl phosphate (PNPP) solution was added, swirled and incubated at $37^{\circ} \mathrm{C}$. After 1 hour, $1 \mathrm{ml}$ of $0.5 \mathrm{M}$ calcium chloride and $4 \mathrm{ml}$ of $0.5 \mathrm{M}$ sodium hydroxide were added. Thoroughly mixed soil suspension was filtered and absorbance measured at $400 \mathrm{~nm}$ on spectrophotometer.

\section{Statistical analysis}

The agronomical data and soil enzyme data were tested for normality and homogeneity of the variance. Two- way analysis of variance (ANOVA) was used to determine significant differences between the D. sissoo cultivars. In the glass house nursery trial agronomic parameters and soil enzyme activities directly depend upon inoculation of $P$. koreensis and thus served as dependent variables.

\section{Results and Discussion}

Impact of $P$. koreensis on biomass of $D$. sissoo cultivars

In both the $D$. sissoo cultivars inoculation had an overall positive effect on seedling growth. However, the performance of Pseudomonas koreensis inoculated seedlings was cultivar specific. In treated seedlings nodule number, root length, shoot length, shoot fresh weight and root fresh weight was higher in PS90 cultivar as compared to PS52 cultivar.

At 30 DAP the shoot length in Pseudomonas koreensis inoculated PS90 seedlings was 30 $\mathrm{cm}(\mathrm{T} 2=\mathrm{CMC}+$ Pseudomonas koreensis $)$ and $40 \mathrm{~cm}$ (T3= GA + Pseudomonas koreensis) which was significantly higher than untreated control (T1= PS 90 Control) $25 \mathrm{~cm}$. Similar pattern was observed at 45 and 60 DAP also. The shoot length at 45 days treatments in treated (T2, T3) and untreated (T1) was 35.4, 44.6 , and $33 \mathrm{~cm}$ whereas at 60 DAP shoot length in treated (T4, T6) and untreated (T4) was $35.8,39$ and $34 \mathrm{~cm}$ respectively. The similar trend was observed for shoot fresh weight, root fresh weight and root length also. In PS 52 cultivar similar variation was observed. At 30 DAP the shoot length in Pseudomonas koreensis inoculated PS52 seedlings was $32 \mathrm{~cm} \quad(\mathrm{~T} 5=\mathrm{CMC}+$ Pseudomonas koreensis) and $35 \mathrm{~cm}(\mathrm{~T} 6=\mathrm{GA}$ + Pseudomonas koreensis) which was significantly higher than uninoculated control i.e., T4= PS 52 control. Similar pattern was observed at 45 DAP where shoot length in treated (T4, T6) and untreated (T4) was $35.8 \mathrm{~cm}, 39 \mathrm{~cm}$ and $34 \mathrm{~cm}$ and 60 DAP where shoot length in treated (T4, T6) and untreated (T4) shoot length was $36.4,40$ and $36 \mathrm{~cm}$ respectively (Table 1). The similar trend was observed for shoot fresh weight, root fresh weight and root length also). Amongst the adhering agents $\mathrm{CMC}$ and $\mathrm{GA}$ both shows the positive effect on D. sissoo seedlings, indicating that the positive effect on seedling growth was due to inoculation of Pseudomonas koreensis AS15 strain only.

Impact of $P$. koreensis on soil microbiological activity

\section{Alkaline phosphatase}

Alkaline phosphatase is the measure of phosphorous recycled in the soil. Significant increase in the activity with sampling time was observed in case of $D$. sissoo cultivar PS90 as well as PS 52 cultivar. At 30 days the alkaline phosphatase activity of treated (T2, T3) and untreated (T1) seedlings of cultivars PS 90 was 31, 15.76 and $9.86 \mathrm{\mu gml}^{-1} \mathrm{hr}^{-1}$ respectively.

The alkaline phosphatase activity of treated (T4, T6) and untreated (T4) PS52 seedlings was 25,35 and $17 \mathrm{gml}^{-1} \mathrm{hr}^{-1}$ respectively. Similar trend was observed at 45 and 60 DAP in both the cultivars of D. sissoo at 45 and 60 DAP (Fig. 1). 
Fig.1 Effect of inoculation of Pseudomonas koreensis strain AS15 inoculation on alkaline phosphatase (AP) and fluorescein diacetate (FDA) hydrolysis activities in two different D. sissoo cultivars PS 90 (A) and PS 52 (B) at nursery stage
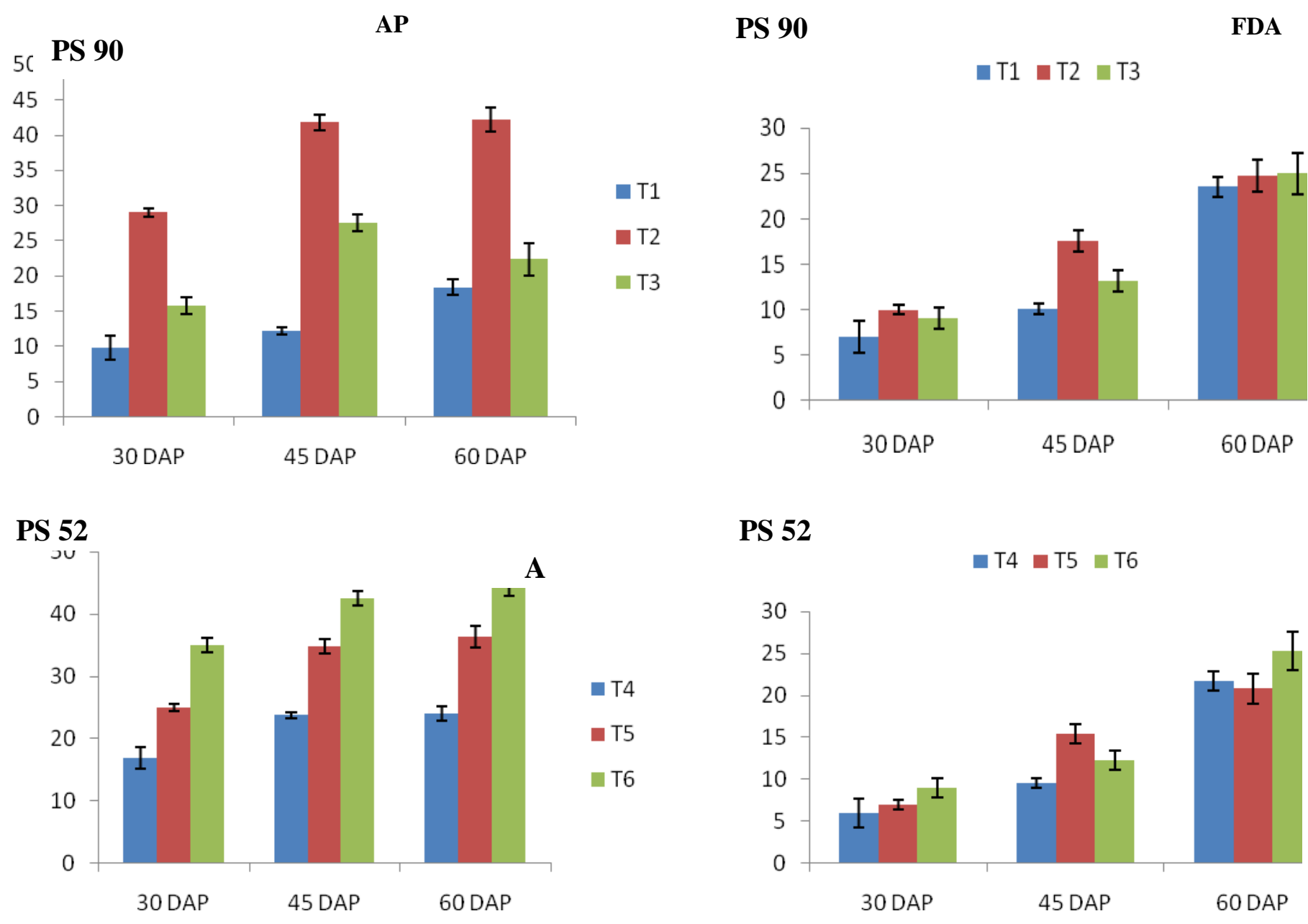

\section{PS 52}

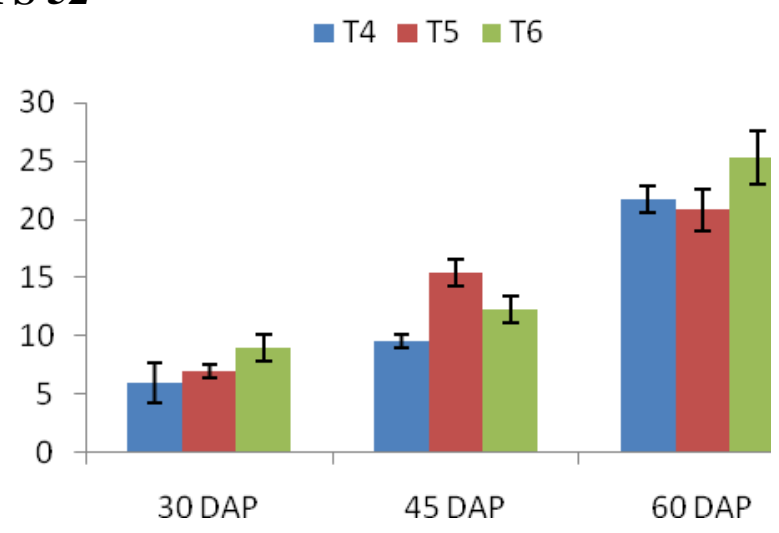

B 
Fig.2 Correlation analysis between FDA and AP activities in two D. sissoo cultivars PS 52 (A) and PS 90 (B) at 45 days using Rsoftware tool

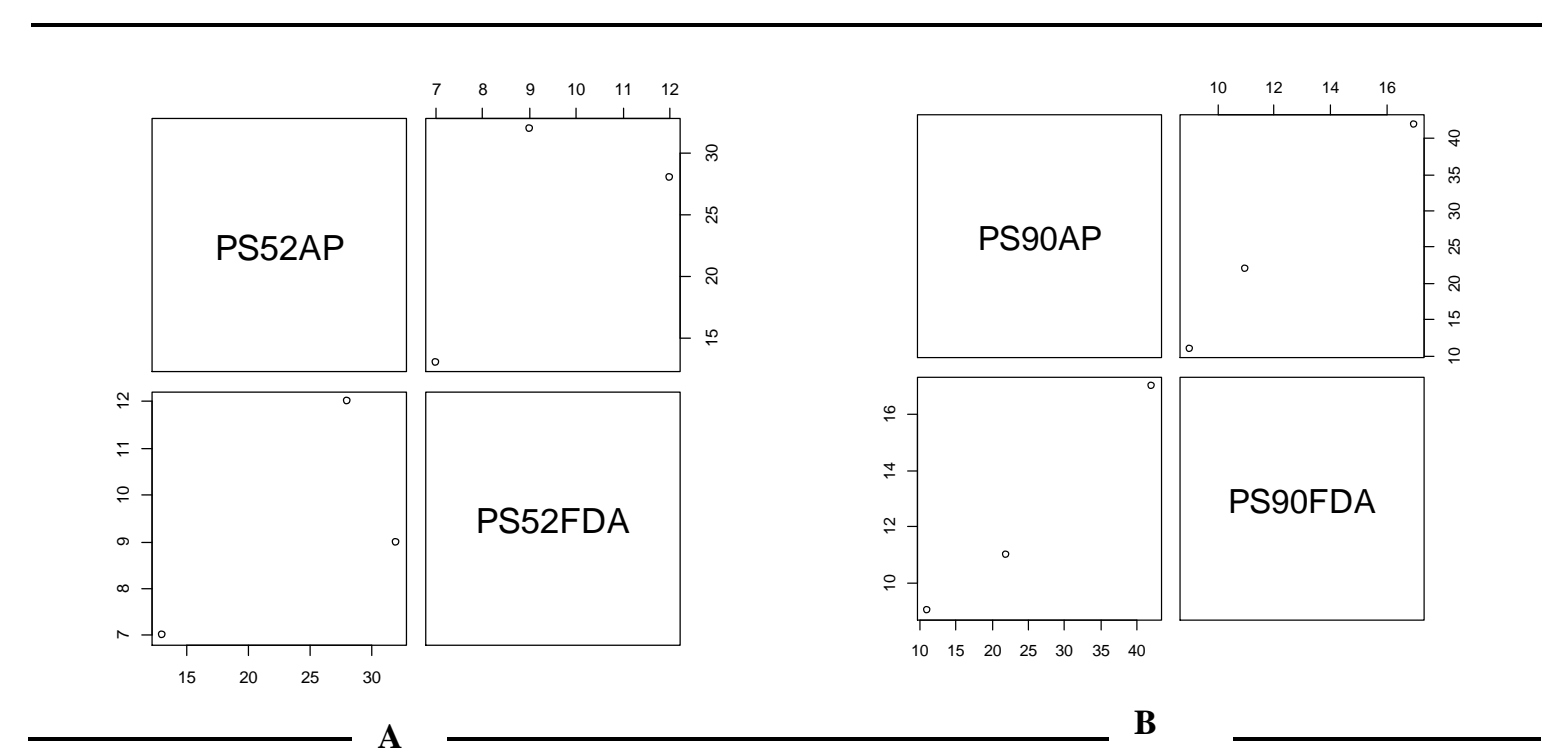

Table.1 Effect of Pseudomonas koreensis strain AS15 inoculation on plant vigor parameters of two D. sissoo cultivars PS 90 and PS 52 at nursery stage

\begin{tabular}{|c|c|c|c|c|c|c|c|c|c|c|c|c|c|c|c|}
\hline \multicolumn{16}{|c|}{ PLANT AGRONOMIC PARAMETER } \\
\hline TREATMENT & \multicolumn{3}{|c|}{30 DAP } & \multicolumn{5}{|c|}{45 DAP } & \multicolumn{2}{|c|}{60 DAP } & \multirow{3}{*}{$\begin{array}{l}\text { SFW } \\
\text { (gm) } \\
5.8^{\mathrm{AB}^{\mathrm{B}}} \pm 0.461\end{array}$} & \multirow{3}{*}{$\begin{array}{l}\mathbf{S L} \\
(\mathbf{c m}) \\
44.4^{\mathrm{B}} \pm 0.2 \\
3\end{array}$} & \multirow{3}{*}{$\begin{array}{l}\text { RFW } \\
\text { (gm) } \\
2.8^{\mathrm{B}} \pm 0.05 \\
7\end{array}$} & \multirow{3}{*}{$\begin{array}{l}\mathbf{R L} \\
(\mathbf{c m}) \\
17.6^{\mathrm{A}} \pm 0.346\end{array}$} & \multirow{3}{*}{$\begin{array}{l}\text { NODULE } \\
\text { NO. } \\
15 \pm 2.30\end{array}$} \\
\hline & $\begin{array}{l}\text { SFW } \\
(\text { gm) }\end{array}$ & $\begin{array}{l}\text { SL } \\
(\mathbf{c m})\end{array}$ & $\begin{array}{l}\text { RFW } \\
\text { (gm) }\end{array}$ & $\begin{array}{l}\text { RL } \\
(\mathbf{c m})\end{array}$ & $\begin{array}{l}\text { NODULE } \\
\text { NO. }\end{array}$ & $\begin{array}{l}\text { SFW } \\
(\text { gm) }\end{array}$ & $\begin{array}{l}\text { SL } \\
(\mathbf{c m})\end{array}$ & $\begin{array}{l}\text { RFW } \\
\text { (gm) }\end{array}$ & $\begin{array}{l}\text { RL } \\
(\mathbf{c m})\end{array}$ & $\begin{array}{l}\text { NODULE } \\
\text { NO. }\end{array}$ & & & & & \\
\hline T1 (control) & $1.1^{\mathrm{A}} \pm 0.115$ & $25^{\mathrm{A}} \pm 0.1$ & $\begin{array}{l}0.56^{\mathrm{A}} \pm 0.01 \\
1\end{array}$ & $9^{\mathrm{A}} \pm 0.577$ & 0 & $2.3^{\mathrm{A}} \pm 0.230$ & $33^{\mathrm{A}} \pm 1.732$ & $\begin{array}{l}1.3^{\mathrm{A}} \pm 0.2 \\
30\end{array}$ & $77.1^{\mathrm{A}} \pm 0.05$ & $4 \pm 1.154$ & & & & & \\
\hline $\mathrm{T} 2$ & $1.2^{\mathrm{A}} \pm 0.230$ & $\begin{array}{l}30^{\mathrm{B}} \pm 00 . \\
577\end{array}$ & $0.8^{\mathrm{A}} \pm 0.199$ & $\begin{array}{l}18^{\mathrm{C}} \pm 1.15 \\
4\end{array}$ & $7 \pm 1.154$ & $3.2^{\mathrm{B}} \pm 0.115$ & $\begin{array}{l}35.4^{\mathrm{B}} \pm 0.2 \\
30\end{array}$ & $\begin{array}{l}2.1^{\mathrm{B}} \pm 0.1 \\
15\end{array}$ & $21^{\mathrm{B}} \pm 1.154$ & $11 \pm 0.057$ & $4.6^{\mathrm{AB}} \pm 0.173$ & $\begin{array}{l}36.2^{\mathrm{A}} \pm 0.4 \\
61\end{array}$ & $\begin{array}{l}1.4^{\mathrm{A}} \pm 0.1 \\
732\end{array}$ & $21.5^{\mathrm{B}} \pm 0.288$ & $18 \pm 1.154$ \\
\hline $\mathrm{T} 3$ & $1.8^{\mathrm{B}} \pm 1.304$ & $\begin{array}{l}40^{C} \pm 0.1 \\
73\end{array}$ & $0.9^{\mathrm{B}} \pm 0.057$ & $\begin{array}{l}10^{B} \pm 1.15 \\
4\end{array}$ & 0 & $3.3^{\mathrm{B}} \pm 0.173$ & $\begin{array}{l}44.6^{c} \pm 0.1 \\
15\end{array}$ & $\begin{array}{l}1.4^{\mathrm{A}} \pm 0.1 \\
73\end{array}$ & $22.4^{\mathrm{B}} \pm 0.230$ & $6 \pm 0.577$ & $5.8^{\mathrm{AB}} \pm 0.173$ & $\begin{array}{l}45.6^{\mathrm{B}} \pm 0.3 \\
46\end{array}$ & $\begin{array}{l}1.6^{\mathrm{A}} \pm 0.3 \\
46\end{array}$ & $25^{\mathrm{C}} \pm 1.154$ & $16 \pm 0.577$ \\
\hline CD AT $5 \%$ & 0.22 & 1.3 & 0.24 & 0.9 & & 0.44 & 1.45 & 0.6 & 1.54 & & 0.77 & 1.45 & 0.6 & 1.54 & \\
\hline T4 (control) & $1.6^{\mathrm{AB}} \pm 0.305$ & $\begin{array}{l}30^{\mathrm{A}} \pm 1.7 \\
32\end{array}$ & $\begin{array}{l}0.85^{\mathrm{C}} \pm 0.01 \\
1\end{array}$ & $16^{\mathrm{B}} \pm 2.30$ & $5 \pm 1.154$ & $2.6^{\mathrm{B}} \pm 0.230$ & $34^{\mathrm{A}} \pm 0.577$ & $\begin{array}{l}1.4^{\mathrm{B}} \pm 0.1 \\
55\end{array}$ & $21^{\mathrm{A}} \pm 2.30$ & $12 \pm 1.154$ & $2.5^{\mathrm{A}} \pm 0.288$ & $\begin{array}{l}36^{\mathrm{A}} \pm 0.11 \\
5\end{array}$ & $\begin{array}{l}1.5^{\mathrm{AB}} \pm 0.2 \\
3\end{array}$ & $21.5^{\mathrm{A}} \pm 0.115$ & $24 \pm 1.154$ \\
\hline T5 & $1.8^{\mathrm{B}} \pm 0.057$ & $\begin{array}{l}32^{\mathrm{B}} \pm 1.1 \\
54\end{array}$ & $\begin{array}{l}0.11^{\mathrm{A}} \pm 0.02 \\
3\end{array}$ & $\begin{array}{l}15^{\mathrm{B}} \pm 1.15 \\
4\end{array}$ & $8 \pm 1.154$ & $2.4^{\mathrm{B}} \pm 0.057$ & $\begin{array}{l}35.8^{\mathrm{B}} \pm 0.1 \\
55\end{array}$ & $\begin{array}{l}1.2^{\mathrm{A}} \pm 0.2 \\
30\end{array}$ & $23^{\mathrm{B}} \pm 1.154$ & $12 \pm 2.30$ & $2.6^{\mathrm{B}} \pm 0.577$ & $\begin{array}{l}36.4^{\mathrm{A}} \pm 0.2 \\
30\end{array}$ & $\begin{array}{l}1.4^{\mathrm{A}} \pm 0.1 \\
73\end{array}$ & $24^{\mathrm{B}} \pm 0.115$ & $24 \pm 1.732$ \\
\hline T6 & $1.0^{\mathrm{A}} \pm 0.173$ & $\begin{array}{l}35^{\mathrm{C}} \pm 2.3 \\
09\end{array}$ & $0.6^{\mathrm{B}} \pm 0.173$ & $\begin{array}{l}10^{\mathrm{A}} \pm 0.57 \\
7\end{array}$ & 0 & $1.9^{\mathrm{A}} \pm 0.115$ & $39^{\mathrm{C}} \pm 0.577$ & $1.2^{\mathrm{A}} \pm 0$ & $24^{\mathrm{B}} \pm 1.732$ & $7 \pm 1.154$ & $2.5^{\mathrm{A}} \pm 0.115$ & $\begin{array}{l}40^{B} \pm 0.57 \\
7\end{array}$ & $\begin{array}{l}1.7^{\mathrm{B}} \pm 0.11 \\
5\end{array}$ & $24.8^{\mathrm{C}} \pm 0.115$ & $25 \pm 2.309$ \\
\hline CD AT $5 \%$ & 0.6 & 1.2 & 0.06 & 1.3 & & 0.3 & 1.21 & 0.01 & 1.1 & & 0.06 & 1.3 & 0.2 & 0.3 & \\
\hline
\end{tabular}




\section{Fluorscein di acetate hydrolysis}

The amount of FDA hydrolyzed is a measurement of total soil microbial activity. FDA hydrolysis activity also varies significantly in both the treated cultivars of D.sissoo PS90 and PS52 as compared to their respective controls at all sampling times. At 30 days the fluroscein di acetate hydrolysis activity in rhizospheric soil of treated (T5, T6) and untreated (T4) PS90 plants were 10, 9 and $7 \mu \mathrm{gml}^{-1} \mathrm{hr}^{-1}$ respectively. Whereas, fluorescein diacetate hydrolysis acticity in rhizospheric soil of treated (T5, T6) and untreated (T4) PS52 seedlings was 7, 9 and 6 $\mu \mathrm{gml}^{-1} \mathrm{hr}^{-1}$ respectively. The trend was similar in both Dalbergia sissoo cultivars at 45 and 60 DAP (Fig. 1).

The results of this study clearly showed that i) there is overall positive impact of $P$. koreensis AS15 inoculation on agronomic parameters of both the $D$. sissoo cultivars i.e., PS 90 and PS 52, and ii) inoculation of $P$. koreensis AS15 enhances soil microbiological activities e.g. AP and FDA of two D. sissoo cultivar PS 90 and PS 52. At 30 DAP plant agronomic parameters in treated cultivar were enhanced in treated seedlings for example, shoot length in treated PS 90 seedlings (T2, T3) and was 35.4 and $44.6 \mathrm{~cm}$ respectively whereas in untreated control (T1) was $25 \mathrm{~cm}$. At 60 DAP shoot length in treated cultivar PS 52 seedlings ( $\mathrm{T} 5$ and $\mathrm{T} 6$ ) was 36.4 and $40 \mathrm{~cm}$ respectively whereas in control (T4) $36 \mathrm{~cm}$. Root length, shoot fresh weight, root fresh weight also showed the similar trend. This increase in the plant agronomic parameters may be due to inhibition of soil borne pathogen upon inoculation of P.koreensis AS15. The inhibition is either due to secretion of antifungal metabolites (Lee et al., 2003), or competitive exclusion of pathogen through rapid colonization in the rhizospheric region (Haas and Defago, 2005). The increase in root and shoot parameters in Pinus taeda seedlings treated with Pseudomonas fluorescens have also been reported (Fernandes et al., 2018). In present study AP and FDA show positive correlation analyzed with R-software tool at 45 days which signify that increase in total microbial activity increases alkaline phosphatase activity which results in the release of free phosphate for the uptake by plants. This directly enhances the plant growth (Fig. 2). There was substantial positive effect on plant growth, development and physiology upon inoculation with strains belonging to genus Pseudomonas sp. through a combination of direct and indirect mechanisms (Upadhyay and Srivastava, 2008). Moreover Dalbergia latiffolia nursery inoculated with rhizospheric bacteria exhibited enhancement in all the agronomic parameters (Soumaya et al., 2017).

From the results of our investigation it is clearly evident that inoculation of P.koreensis AS15 clearly significantly enhanced the overall growth parameters of D.sissoo seedlings. However, the enhancement was cultivar specific. The impact was more in PS90 cultivar as compared to PS52. In addition to this, inoculation of P.koreensis AS15 strain significantly enhanced soil alkaline phosphatase and fluorescein diacetate hydrolysis activities indicating higher availability of phosphate and carbon for plant uptake. Thus bacterization of PS90 seedlings with P.koreensis AS15 could result in quality planting material.

\section{Acknowledgement}

The authors acknowledge the financial support provided by ICAR-GoI, New Delhi.

\section{References}

Afzal, M., R.M. Rafique, A.A. Chaudhry, A.R. Chaudhry and A.M. Akhtar, (2006). Shisham dieback research at 
PFRI. In: Proc. 3rd Nat. Sem. Shisham Dieback, May 11, 2006. Punjab Forestry Research Institute, Faisalabad, Pakistan. pp. 16-28.

Ahemad, M. and Kibret, M. (2014). Mechanisms and applications of plant growth promoting rhizobacteria: Current perspective. J. King Saud Uni. Sci. 26, 1-20.

Ahemad, M., and Khan, M. S. (2012). Effect of fungicides on plant growth promoting activities of phosphate solubilizing Pseudomonas putida isolated from mustard (Brassica compestris) rhizosphere. Chemosphere, 86(9), 945-950.

Ahmad, B. I., Khan, R. A., and Siddiqui, M. T. (2013). Incidence of dieback disease following fungal inoculations of sexually and asexually propagated shisham (Dalbergia sissoo). Forest Pathology, 43(1), 77-82.

Ahmed, S., Pathak, D. V., Kumar, M., and Phogat, D. S. (2016). Isolation and characterization of plant growth promoting Rhizobacterfrom rhizosphere of Shisham (Dalbergia sissoo).

B.R. Glick (2012). Plant Growth-Promoting Bacteria: Mechanisms and Applications Hindawi Publishing Corporation, Scientifica.

Binkley, D. and Giardina, C. (1997). Nitrogen fixation in tropical forest plantations. In: Management of Soil, Nutrients and Water in Tropical Plantation Forests (eds Nambiar, E.K.S. \& Brown, A.G.). Australian Centre for International Agricultural Research, Canberra, Australia, pp. 297-338.

Binkley, D., Cromack, K. Jr and Baker, D.D. (1994). Nitrogen fixation by red alder: biology, rates and controls. In: The Biology and Management of Red Alder (eds Hibbs, D., DeBell, D. \& Tarrant, R.). Oregon State University Press, Corvallis, OR, pp. 57-72.
Bisht R., Chaturvedi S., Srivastava R., Sharma A.K., Johri B.N. (2009): Eff ect of arbuscular mycorrhizal fungi, Pseudomonas fluorescens and Rhizobium leguminosarum on the growth and nutrient status of Dalbergia sissoo Roxb. Tropical Ecology, 50: 231-242

Cakmak1 R, Kantar F, Fiahin F (2001). Effect of N2-fixing bacterial inoculations on yield of sugar beet and barley. J. Plant Nutr. Soil Sci. 164: 527-531.

Dayaram, M. K., Sharma, S., and Chaturvedi, O. P. (2003). Shisham mortality in Bihar extent and causes. Indian Phytopathology, 56(4), 384-387.

Fernandes dos Santos, Rafael and Purin, Sonia and Botelho, Gloria and Vasconcelos Flores, Andressa. (2018). Inoculation of Pinus taeda Seedlings with Plant Growth-promoting Rhizobacteria. Floresta e Ambiente. 25 10.1590/2179-8087.005616.

Frąc, M. and S. Jezierska-Tys (2011). Agricultural utilisation of dairy sewage sludge: its effect on enzymatic activity and microorganisms of the soil environment. Afr. J. Microbiol. Res. 5, 1755-1762.

Gholami, A., Shahsavani, S., and Nezarat, S. (2009). The effect of plant growth promoting rhizobacteria (PGPR) on germination, seedling growth and yield of maize. Int J Biol Life Sci, 5(1), 35-40.

Gill, M.A., I. Ahmad, A.U. Khan, M. Aslam, S. Ali, R.M. Rafique and M. Khan (2001). Phytophthora cinnamomi A cause of shisham decline in Punjab, Pakistan. Proc. of 3rd Natl. Cont. of Plant Pathol. Oct. 1-3, NARC, Islamabad, pp. 33-37.

Glick., B.R. (2012). Plant growth-promoting bacteria: mechanisms and applications. Scientifica, 2012.

Haas, D., and Défago, G. (2005). Biological control of soil-borne pathogens by 
fluorescent pseudomonads. Nature reviews microbiology, 3(4), 307.

Inbar, Y., Boehm, M. J., and Hoitink, H. A. (1991). Hydrolysis of fluorescein diacetate in sphagnum peat container media for predicting suppressiveness to damping-off caused by Pythium ultimum. Soil Biology and Biochemistry, 23(5), 479-483.

Jezierska-Tys, S., Rachoñ, L., Rutkowska, A., \& Szumi ${ }^{3}$ o, G. (2011). Microbial populations and enzymatic activity in soil under winter wheat. Int. Agrophys, 25, 21-26.

Khan, A. G. (2005). Role of soil microbes in the rhizospheres of plants growing on trace metal contaminated soils in phytoremediation. Journal of Trace Elements in Medicine and Biology, 18(4), 355-364.

Kloepper, J.W., Lifshitz, R. and Zablotowicz, R.M. (1989). Free living bacterial inocula for enhancing crop productivity. Trends in Biotechnology, 7: 39-44

Lee, J.Y., Moon, S.S., and Hwang, B. K. (2003). Isolation and antifungal and antioomycete activities of aerugine produced by Pseudomonas fluorescens strain MM-B16. Applied and environmental microbiology, 69(4), 2023-2031.

Padder, S.A., Pathak, D.V., Bhat, Z.A. and Kuldeep. (2017). Characterization of Plant Growth Promoting Rhizobacteria from Rhizosphere of Shisham (Dalbergia sissoo) and their Effect against Fungal Pathogens. Int. J. Pure App. Biosci. 5(2): 652-660

Rahmoune, B., Morsli, A., Khelifi-Slaoui, M., Khelifi, L., Strueh, A., Erban, A., and van Dongen, J. T. (2017). Isolation and characterization of three new PGPR and their effects on the growth of Arabidopsis and Datura plants. Journal of plant interactions, 12(1), 1-6.
Rincón, A., Valladares, F., Gimeno, T. E., and Pueyo, J. J. (2008). Water stress responses of two Mediterranean tree species influenced by native soil microorganisms and inoculation with a plant growth promoting rhizobacterium. Tree physiology, 28(11), 1693-1701.

Ruess, R.W., McFarland, J.M., Trummer, L.M. and Rohrs-Richey, J.K. (2009). Disease-mediated declines in N-fixation inputs by Alnus tenuifolia to earlysuccessional floodplains in interior and south-central Alaska. Ecosystems, 12, 489-502.

Sah, S. P., UPADHYAY, S., and Pandit, P. (1999). Assessing the effects of physical properties of soil on sissoo (Dalbergia sissoo, Roxb.) growth in a plantation forest. Final report submitted to DANIDA/HMG, Nepal, 51.

Sah, S.P., C.K. Sharma and F. Sehested. (2003). Possible role of the soil in the sissoo forest (Dalbergia sissoo Roxb.) decline in the Nepal Terai. Plant Soil Environ., 49: 378-385.

Shaheen, S.A., El, Taweel, A.A. and Omar, M.N.A. (2014). Effect of inoculation by some plant growth promoting rhizobacteria (pgpr) on production of 'manzanillo' olive trees. Acta Hortic. $1018,245-254$

Shukla N.A. (2008). Resistance of Dalbergia sissoo to Fusarium solani f.sp. Dalbergiae. Forest Pathology. 38. 410 418. 10.1111/j.1439-0329.2008.00563. $\mathrm{x}$.

Soumya R.N, Ranjan, M Panigrahi and Gupta, N (2017). Impact of Microbial Application on Growth \& Development of Dalbergia latifolia \& Dalbergia sissoo under Nursery Condition. International journal of Environmental Science and Natural Resource Volume 2 Issue4 - May 2017 DIO: 10.19080/IJESNR.2017.02.555592. 
Tabatabai, M. A., and J.M. Bremner (1969). "Use of p-nitrophenyl phosphate for assay of soil phosphatase activity." Soil biology and biochemistry 1, no. 4: 301307.

Upadhyay, A., and Srivastava, S. (2010). Evaluation of multiple plant growth promoting traits of an isolate of Pseudomonas fluorescens strain Psd.

Valdez, N., Karlovsky, P., Dobrindt, L., Hoque, M. I., Sarker, R. H., Tantau, H., \& Mühlbach, H. P. (2013). Role of bacteria in dieback disease of Dalbergia sissoo roxb. Bangladesh Journal of Botany, 42(1), 1-16.
Vitousek, P. M., Menge, D. N., Reed, S. C., and Cleveland, C. C. (2013). Biological nitrogen fixation: rates, patterns and ecological controls in terrestrial ecosystems. Philosophical Transactions of the Royal Society of London B: Biological Sciences, 368(1621), 20130119.

Walley, F.L. and J.J. Germida. 1997. Response of spring wheat (Triticum aestivum) to interactions between Pseudomonas species and Glomus clarum NT4. Biology \& Fertility of Soil 24: $365-371$.

\section{How to cite this article:}

Hemant Dasila, Anjul Rana, Damini Maithani, Anamika Rana, Manvika Sahgal and Salil Tewari. 2018. Interaction between Dalbergia sissoo Roxb. and Pseudomonas koreensis AS15 Strain is Cultivar Specific. Int.J.Curr.Microbiol.App.Sci. 7(10): 297-306.

doi: https://doi.org/10.20546/ijcmas.2018.710.031 